\title{
SOIL RESOURCES AND AGRICULTURAL DEVELOPMENT IN ALASKA*
}

\author{
Allan H. Mick ${ }^{1}$ and Hugh A. Johnson ${ }^{2}$
}

B EFORE the Second World War there was little need for commercial agriculture in Alaska. Most people were living in coastal areas where they could be supplied more economically by water routes from the south. Major potential farming areas, all located in the interior, were far removed from the consuming population. Construction of the Alaska Railroad earlier had stimulated demands for vegetables and potatoes, which were met by a few growers who had drifted to subsistence farming following a gradual collapse of mining as the principal industry in the interior. By the early 1930's these local markets had so deteriorated that plans for colonizing the Matanuska Valley provided only 40-acre and 80-acre part-time subsistence farms, with occupants procuring a major portion of their income from off-farm work.

Although commercial agriculture is new in Alaska, early Russian fur traders raised vegetables in small gardens and imported a few cattle to eke out food supplies between the uncertain visits of their company ships. In the interior, gardens followed the miners and, where horses were brought in to transport freight, a few native grasslands were mowed for hay and later plowed to grow oats and potatoes. Timber was cut for fuel or building materials, and small-scale land clearing followed more or less accidentally.

By 1898 there was sufficient interest in Alaska's agricultural potential to warrant the U.S. Department of Agriculture opening an experimental station at Sitka. In the next two decades six more experimental farms were established. Of these, the Rampart Station in the Yukon Valley was the northernmost; the others were at Fairbanks, Copper Center, Matanuska, Kenai, and Kodiak. All were designed to test crop varieties in subarctic environments. Livestock breeds were introduced at Fairbanks, Matanuska, and Kodiak, the Kodiak farm being closed after the Katmai eruption in 1912 covered the island with ashes, destroying any possibility of growing forage for several years.

Federal interest in these projects languished after they had demonstrated that farming was feasible in what had before been generally regarded as a forbidding land of ice and snow. By mid-1932 only the Fairbanks and Matanuska experimental farms remained, and their operation had been taken over by the University of Alaska. At that time and for several years to come,

*Contribution from the Alaska Agricultural Experiment Station, Palmer, Alaska. Paper 2, Journal Series.

1 Head, Soils Department, Agricultural Experiment Station, Palmer, Alaska.

2Formerly Head, Agricultural Economics Department, Agricultural Experiment Station, Palmer, Alaska (now at Harvard University). 


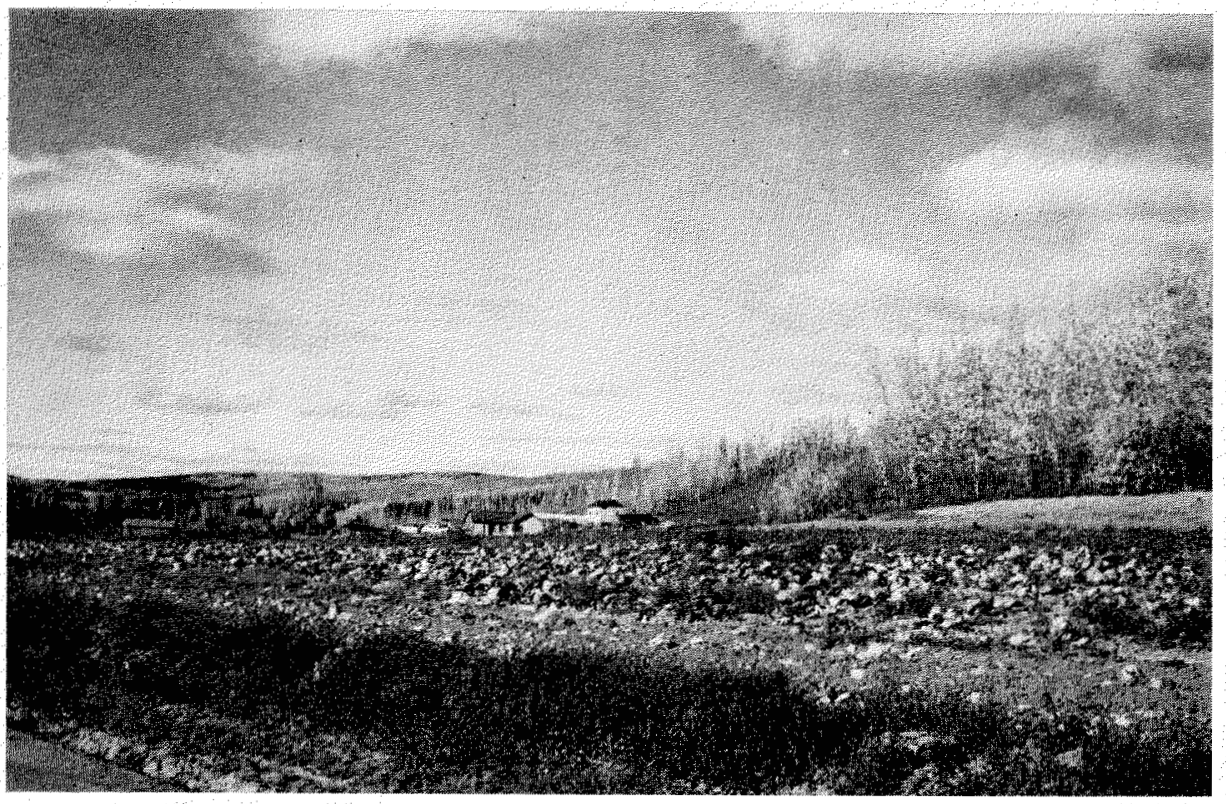

Photo: Alaski Agri. Expt. Sta.

Fig. 1. Vegetable farm on Subarctic Brown Forest soil near Fairbanks. High income vegetable crops are grown for both civilian and military markets. Potatoes, celery, chard, cauliflower, lettuce, cabbage, broccoli, carrots, radishes, and turnips thrive under good management practices.

the Territory lacked an adequate tax structure to support a land-grant college program comparable to those of many states. Little money was budgeted for agricultural research or for extending technical knowledge to the few farm families in the Territory. Pioneer farmers depended chiefly on management practices with which they were familiar, augmented by whatever information a small college staff could gather concerning suitable varieties and practices.

\section{Present scope of commercial agriculture}

The federally sponsored Matanuska Valley colonization was tremendously important in laying the groundwork for commercial agriculture and farm development. In addition to carving fields from the wilderness-a struggle so frustrating that few individuals ever see their places reach full productionthis project created a rural community sufficiently large to support its own service and marketing agencies. A small nucleus of subsistence farms was thus fairly well established before the war. During the war years the demand for local food production fostered commercial farming within this framework. Continued postwar growth of defence establishments has created large stable markets which enabled the community to survive and even expand in the face of great incentives offered by other trades. In the past few years commercial agriculture has grown rapidly and gained in economic importance.

By 1950 there were 878 rural families homesteading, developing farms, and engaged in commercial production in the Territory, but less than half 


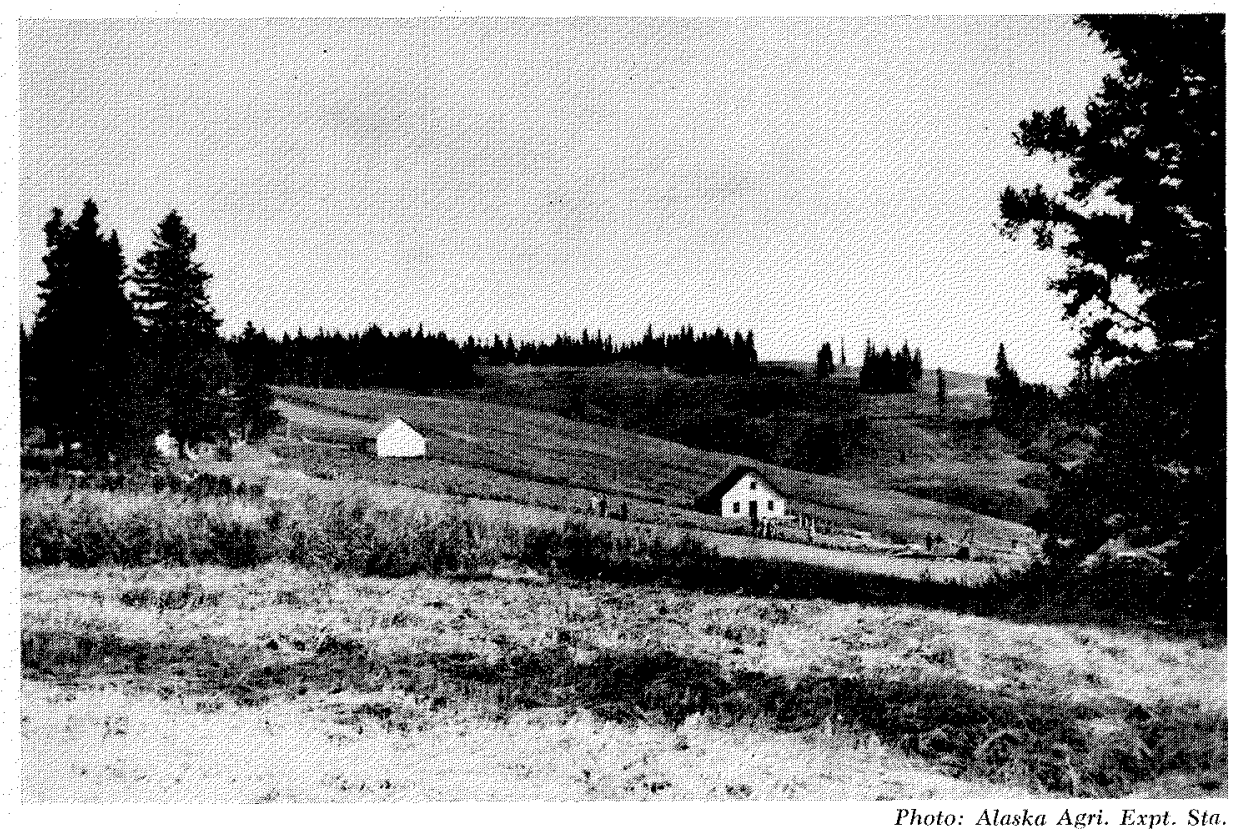

Fig. z. Certitied potato seed is grown on this tarm near Homer, Kenai Peninsula. Soils are fertile and inherently productive, but moderate summer temperatures do not favour grain production. Although well suited to grassland farming, this country lacks an adequate fresh milk market.

depended on farming for their major source of income. Some 300 full-time and part-time farms are now operating in the Matanuska Valley, marketing their crops in Anchorage and nearby military bases; another 35 part-time farms and a dozen or so full-time farms are located in the immediate neighbourhood of Anchorage, while scattered between Kenai and Homer are 40 to 50 partially developed farms, which are expected shortly to send more foodstuffs into Anchorage now that the new highway connections have been completed. A new military market is also emerging near Kenai which should stimulate farming in nearby areas. Another scattered community of about 60 farms is located near Fairbanks. Dairying and grain production are of importance to some farms, while the rest grow vegetables and potatoes for military establishments.

The total farm income in Alaska from sales of foodstuffs amounted to $\$ 2,819,836$ in 1953 . Of this total, fresh milk sales accounted for 38.1 per cent, vegetable and potato sales for 43.4 per cent, livestock products other than milk for 5.3 per cent, and dressed poultry and egg sales for 13.2 per cent. Fur and wool sales were valued at $\$ 180,000$. The value of foodstuffs sold was roughly divided as follows: Matanuska Valley, 56 per cent, Tanana Valley, 16 per cent, southeastern Alaska, 11 per cent, Kenai Peninsula, 6 per cent, Anchorage area, 8 per cent, and Kodiak, Chirikof, and the Aleutian islands, 3 per cent.

In all of Alaska an estimated 13,000 acres were cropped in 1952 while some 3,000 to 5,000 acres of cropland remained idle. Grazing leases covering 


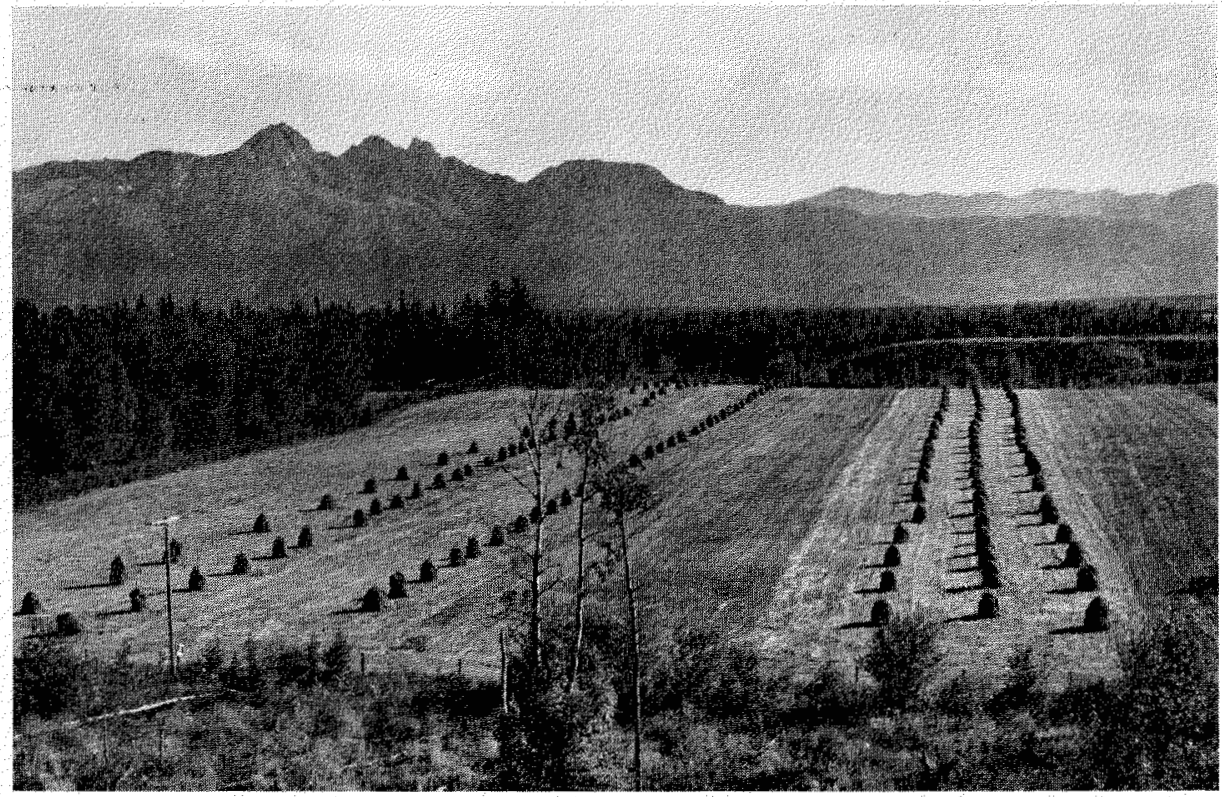

Photo: Alciska Agri. Expt. Sta.

Fig. 3. An oat-pea field in the Matanuska Valley (Knik soil series). Forage from this field was used to compare field curing on stakes with mow drying. Similar research has shown that ensiling is the most practical method of preserving forage in Alaska.

518,00 acres were scattered from Kodiak to Unalaska and Umnak islands in the Aleutian Chain. Grazing rights were also leased on 39,000 acres in the Matanuska-Susitna region. A more accelerated expansion of farming is hindered by high land-clearing costs, an acute lack of venture capital, land speculation, and scarcity of labour. Moreover, present policies are ill-adapted to placing public lands in private ownership under Alaskan conditions, and this combined with a lack of suitable credit discourages rapid settlement by farmers in areas suitable to agriculture. While development of power, improved transportation, and increasing population contribute to ever greater demands for local farm products, incentives to develop new farms are not yet great enough to compete seriously with the high incomes offered by construction and service trades.

On the other hand, efficient dairy farms provide fairly stable employment throughout the year and yield a good living. In 1953, for example, average annual net returns from 38 leading dairy farms amounted to $\$ 4,850$. The average net returns on potato farms is about $\$ 3,500$, and on poultry farms about $\$ 3,000$ a year. Dairying, which is well-adapted to Alaska's natural and economic environment, represents the most stable farm enterprise. Potato and vegetable growing is usually the beginning phase in establishing a farm, though a few specialized potato and vegetable farms are being developed. Further growth is toward dairy enterprises representing a climax type of farming in the Matanuska and Tanana valleys, and today, particularly, to a general type of farming based on poultry, meat, and eggs. 


\section{Soil resources}

Soil development and morphology can supply some clues to a knowledge of the environments of Alaska's farming areas. Mature soils-those that result from the full force of climatic and vegetative soil-forming factors-include only the Tundra and Podzol great soil groups. Podzols are usually found in well-drained sandy surface mantles. Where very fine sands and silts have accumulated, podzolization is feeble and transitional to the intra-zonal Subarctic Brown Forest soils.

\section{Subarctic Brown Forest soils}

Most crop production occurs not on Podzols but on the related welldrained Subarctic Brown Forest soils. Geologically, these soils have weathered for only a short period; hence they have high potash levels but are deficient in organic matter and nitrogen. Available phosphates are usually in short supply. Under cultivation surface layers dry out extremely fast, but, for the most part, these soils respond well to good management practices.

The upland loess mantles near Fairbanks are typical of Subarctic Brown Forest soils, which support a boreal forest. Under a thick peaty carpet a thin acid mineral horizon is stained by intermixed organic matter. At 3 inches or so in depth there occurs a gradual transition to an underlying yellowishbrown, vesicular, leached horizon. At 18 to 24 inches parent material usually is encountered. In the Tanana Valley this is a pale yellow, very fine sandy loam. Tanana Valley soils have developed in deep deposits of wind- and water-transported materials; they contain a lot of mica which is easily transported and are, therefore, subject to severe sheet and gully erosion, especially on the long steep slopes characteristic of the rolling hills near Fairbanks.

In the Matanuska Valley the best farmland consists of well-drained soils in an arrested state of development because their surfaces are continually receiving fresh additions of minerals from the broad beds of the Matanuska and Knik rivers. Both streams distribute a heavy load of glacial rock flour over their channel bars. Dust particles are picked up from there and carried generally westward over adjacent valley plains by strong local winds.

Knik and Bodenburg are the dominant series of the Matanuska Valley Subarctic Brown Forest soils. Both are characterized by banding derived from buried surfaces, by weak stratification, by particle size distributions of a youthful nature, and by wide carbon-nitrogen ratios. Cultivated fields are brown and billowy in topography. Subsoils are drab and mottled by poor drainage. Pore-size distributions are remarkably well-adapted to retaining large quantities of water. Under a climax forest, thick insulating organic mats encourage seasonal frosts to persist until midsummer; this persistent frost further impedes internal drainage. When cleared and cultivated frost layers disappear, internal. drainage develops and these upland soils warm rapidly.

Surface layers of the Subarctic Brown Forest soils are usually acid. Subsoils are well supplied with calcium and magnesium although free carbonates generally are absent. Potash is usually present in adequate quantities for most crops. When cultivated, fields gradually become more alkaline, a process 
associated with organic matter oxidation and a narrowing of carbon-nitrogen ratios. Fields known to be acid when first tilled 20 years ago are now neutral or slightly alkaline. The alkaline reaction of their fields is of immediate concern to many farmers who find their potato crops increasingly afflicted with scab. Sulphur treatments have not proved of value in correcting this soil condition.

\section{Tundra and wet soils}

The Tundra is the most widely distributed zonal great soil group in Alaska. In these soils a variety of vegetal cover subsists at very low levels of activity. Estimates for the recovery of lichens range from 3 years after moderate grazing to as much as 20 or 30 years after severe over-grazing. But even though plant growth is slow, decomposition of organic materials by micro-organisms is still slower. The net result is a thick accumulation of tough, fibrous, peaty material bound together with woody roots, stems, and rhizomes, sluggishly persisting year after year. This carpet is resilient and difficult to traverse except when frozen and covered with snow. In summer it remains saturated. The high insulating properties of this surface layer prevent summer warmth from penetrating mineral substrata which remain frozen for long periods. Most Tundra areas are underlain by permafrost at shallow depths. Small gardens thrive surprisingly well at favoured sites where the surface layer thaws out deeply enough each year.

Low drainage positions are occupied in limited areas by Ground-Water Podzols and over extensive areas by Half Bog soils. Both support rather sparse stands of scrubby black and white spruce. Bog soils locally called "muskeg" are found in undrained depressions and in places underlain by impermeable permafrost, rock, or clay. Some attempts have been made to cultivate wet soils included in farm holdings, but the great hazard of local frost has discouraged any widescale use. At present it seems unwise to encourage extensive drainage because of possible adverse effects on groundwater supplies.

At higher altitudes the intra-zonal Alpine Meadow, Mountain Tundra, and Mountain Half Bog soils are found, and the land appears to have little potential agricultural value except possibly for extensive reindeer grazing or for cattle range where associated with other sites capable of producing winter feed.

\section{Fertilizer requirements}

Farm management practices must include sound conservation principles to preserve the relatively thin surface soils and low organic supplies and to maintain adequate amounts of soil moisture. In addition most soils require generous applications of commercial fertilizers, especially nitrogen and phosphates, even from the very beginning, a fact that sometimes discourages the homesteader. Cultivation stimulates oxidation of soil organic matter and this process competes with crop plants for the little nitrogen inherently available. Nitrogen deficits can be made up by generous applications of nitrogen fertilizers only. 
All fertilizers must be imported, and therefore their cost is high. Ammonium nitrate imports are complicated by a Coast Guard regulation made necessary by the fire hazard in shipping, but at $\$ 7.70$ a hundredweight, it is still the cheapest and most efficient source of nitrogen available to Alaskan farmers.

With proper fertilization forage crops can be grown in abundance. This is one of several reasons why dairying is a logical enterprise. Crop production in Alaska is largely limited to cool-season species. Since the reorganization of the Alaska Agricultural Experiment Station in 1948, field crop research has concentrated on developing and selecting superior varieties of forage and cereal crops and on devising profitable means of producing those crops. The success of Alaska's livestock industry will depend in part on the extent to which these objectives are achieved and put into practice.

\section{Effect of permafrost}

North of the coastal mountain ranges agricultural land use is complicated by the presence of frozen subsoil even in sites where local summer air temperatures are suitable for growing commercial crops. While some permafrost phenomena are inherited from previous climates, others are more closely related to surface aspect and to the development of a climax vegetative cover with its associated insulating surface mat.

Many sites that otherwise appear arable may actually be underlain by ice lenses and blocks. In a few places near Fairbanks clearing and cultivation have apparently improved surface-heat absorption and sub-surface conduction, thus causing underground ice masses to melt. Unequal subsidence of the land surface has made a few acres unfit for further tillage. In other places large sinkholes have appeared. Plans for settlement in the Dunbar area west of Fairbanks were abandoned several years ago because the best surface soils appeared susceptible to this kind of deterioration.

Perhaps of greater significance is the fact that permafrost layers impede vertical drainage. Great expanses of level land remain wet throughout the summer and artificial drainage would require a vast reclamation project. East of Fairbanks a few favourably located sites have been stripped free of their forest and insulating mats, and the permafrost layers appear to be retreating, although vertical drainage has not yet become fully operative.

Another way in which permafrost inhibits the agricultural use of otherwise favourable sites is by interfering with domestic water supplies. In the Tanana Valley only a few satisfactory wells have been drilled in the upland area. Deep wells are both expensive and subject to freezing. Shallow wells are generally unsatisfactory because of limited ground-water supplies and sanitation problems.

\section{Agricultural potential}

Evidence of the kind of agricultural industry that can evolve in Alaska is available from similar natural environments in other parts of the world. In these areas, Tundra soils are generally considered non-agricultural and have 
supported only primitive agricultural societies. Where Podzols are dominant settlements are usually small and have developed as a result of lumbering or mining operations. A subsistence agricultural economy, based on hay, potatoes, and root crops with limited grain production can be supported. Oats are initially grown for horse feed, and later for dairy feed as markets appear for livestock products. Because the climate favours growing forage, dairying has usually emerged as the main agricultural industry. Butter and cheese are important exports, though this is unlikely to occur in Alaska. Supplementary foods and fibres from other climates have to be imported, particularly if industrial growth occurs.

Recent studies indicate that agricultural development in Alaska will conform in part to these historical patterns. Alaska cannot be expected to produce all the food required within the Territory. The population is conditioned to an abundant and varied diet: fats, oils, sugar, legumes, grain products, fruits, and nuts are all staple items, and very few of these can be grown efficiently under subarctic conditions. Fortunately, national trends are toward increased consumption of meat, poultry, eggs, dairy products, and processed vegetables, many of which can be produced locally. Consumption of potatoes, while showing a downward trend in the United States, still greatly exceeds production in Alaska.

Viewed in the historical perspective of the westward population expansion across the United States, Alaska's present status is something of a paradox. A major part of North America was settled by farmers migrating from within, and extending an agricultural economy. During this period, which gave rise to the land laws and a unique land-grant educational system, farming was both the vocation and dominant way of life for most people. Land policies guiding the western migration were based on deliberate attempts to transfer public lands to private ownership. This device succeeded in broadening the revenue base supporting local governments and public services.

Many factors adversely influencing Alaska's agricultural growth are rooted in social changes occurring in the United States during the past halfcentury. Conspicuous among these changes is a decrease in the proportion of people on farms. Equally conspicuous is the high level of living won by those families remaining on farms. High farm living standards have always been basic to the national policy but a clear enunciation has emerged only in the last two decades.

Alaska's homesteading population reflects these changes in social structure and thinking. For example, homesteaders who grew up on farms or who had farming experience before coming to the Territory are definitely a minority. Most new settlers came from urban backgrounds where they were conditioned to highly organized public services and facilities. Many arrived and continue to arrive without adequate financial resources. On their homesteads they find that living standards to which they have been accustomed require large cash incomes that can be obtained during early developmental stages through off-farm labour only. Mechanization of farm operations and modern farm plants require additional cash outlays far in excess of what their 
grandfathers found necessary in opening the 'west'. Beginning farmers are thus forced into off-farm employment to supplement their part-time farming enterprises in which risks are relatively high. Opportunities for off-farm work have been good, wages are attractive, and working conditions are more satisfactory to the former city dweller than those found in clearing and breaking land. Basic incentives in Alaska therefore tend to pull people away from the land. Antiquated land laws do not offer sufficient counter-incentives to reverse this trend. Historical pressures toward private land ownership are not effective in encouraging farming in modern Alaska.

Even the fairly well established farms are in a state of flux. Among fewer than 100 full-time farmers in the Matanuska Valley there were 25 farm transfers during the years 1951-3. Half of these departing families "were not adapted" in the minds of two long-time residents. Others left because of advancing age or poor health. This large turnover of commercial farms hinders the development of long-term farm management practices and the emergence of a sound food-producing economy.

An encouraging tendency is noted in recent Territorial legislation, which provides an appropriation for farm development and crop loans. Though the fund of $\$ 200,000$ is small it has assisted in reducing a part of the risk now burdening Alaska's farmers. This legislation was an effective expression of faith in Alaska's future. It has served to reassure sources of private credit and entrepreneurs primarily interested in farming, small business, and processing industries.

\section{Food potential}

An index of Alaska's food producing potential is given in a recent figure which shows that 0.3 to 0.4 acre of good land per person is required to produce those food items that can be grown in the Territory at the present time, exclusive of beef and mutton. In contrast total land requirements for average national diets vary between 2.1 to 2.4 acres per person. Alaska therefore can be expected to provide only 12 to 20 per cent of the over-all acreage requirements of the population. Translated into terms of bulk, the products from this acreage might comprise from 30 to 40 per cent of total foodstuffs consumed in a well-balanced economy.

Present cleared acreages in the Railbelt are sufficient to supply a population of some 44,000 with that portion of their food requirements that can be grown locally. However, the permanent civilian population of this area is now estimated at 100,000 , and during the summer the permanent population is supplemented by at least 20,000 transients, either touring or employed in construction trades. In addition four large military defence establishments swell local food demands. Doubling the present cropland areas still would not bring supply into line with demand. Present cropland areas could probably be tripled with little danger of over-supply, provided that most of the additional land is used for milk or meat production.

Despite great demands, which are reflected in high food prices, farm development is slow. During the past five years some 600 to 700 acres only 
were cleared annually in the Railbelt. In the Matanuska Valley land-clearing lags even on established farms with considerable acreage available within their holdings. Dairy farms need from 25 to 30 per cent more cropland in order to operate most efficiently.

What justifies continued emphasis on developing Alaska's agriculture? Although the climate is subarctic throughout most of the Territory, there are several large areas of fairly good soils where local climates favour cool-season crops and forage. Experience has proved that cereals will mature and even tomatoes will ripen in the short summers of the Yukon Valley. Farther south, near Fairbanks, the frost-free period is long enough for cereals and forage, although summer temperatures are generally too low for warm-season vegetables such as beans and tomatoes. The coastal climate of the Kenai Peninsula is marked by longer frost-free seasons but also by lower summer temperatures which prevent cereals from ripening except in favourable years. Forage thrives in this environment which is well-adapted to dairying based on high protein silage feeds, and cool-season vegetables and potatoes also grow well.

Estimates of arable acreages in Alaska vary widely. Many figures have been derived from assumptions that all potential areas are equally accessible and that marketing opportunities are similar. Some estimates have assumed full exploitation of grazing lands remote from sites capable of producing winter feed. Assuming only an expansion of present social and economic patterns, and stipulating that most farmland will be used to produce those crops considered in the per capita acreage index mentioned above, the total area of potentially good cropland in Alaska probably amounts to about one million acres. Full utilization of this potential will supply part of the food requirements (exclusive of meat) for perhaps two and a half million people. Again assuming that future growth proceeds according to present patterns, this area might support 9,000 to 10,000 farms sending marketable surpluses to trade channels. If part of this cropland is diverted to meat production, per capita acreage requirements for food grown in Alaska might approach 0.8 acre; full use of Alaska's cropland along these lines would support some 5,000 to 6,000 farms growing some 60 per cent of the food requirements for a population of perhaps one million.

In addition there are perhaps half a million acres of poorer land associated with this good cropland. Small areas are now grazed; other areas in individual holdings may be included in farm management systems to supplement income from good land; and still others may lend themselves for extensive cropping practices like summer grazing or pulp growing. Only a small fraction of this poor land alone will support farms. Good use can be obtained only in conjunction with better areas in a well coordinated management program.

There is also an estimated 4 million to 6 million acres of summer grazing land. As mentioned, some coastal areas of this kind of land are already under lease. Other areas, notably in the interior where winters are severe, may never be used in the forseeable future because winter feeding and shelter require excessive capital outlays under the present economy. Where near farms that can provide shelter and winter feed, small areas are currently being 
used for summer grazing. For example, a small valley in the Talkeetna Mountains, which bound the Matanuska Valley on the north, was used as summer range for dairy cattle during 1954.

Several million acres of grasslands also exist on Kodiak and other islands to the westward. Experience to date has indicated that livestock, such as cattle and sheep, can live and flourish on these islands on a year-round basis. Transportation, marketing, and other problems have been limiting factors.

When critical land needs develop in the North American continent it is possible that considerably more than a million acres may be farmed in Alaska. It is unlikely that full use of Alaska's agricultural land will occur until after other more southerly agricultural areas are fully exploited.

It is anticipated that the bulk of Alaska's consuming population will be located in the mainland, since experience has proved that southeastern coastal settlements cannot be supplied efficiently against competition from the south. With favourable shipping costs there is a definite possibility of exporting food from Alaska to Japan and other over-populated Oriental areas, but it will require high production efficiency. Shipping may be tied in with wood export, a development that appears to be nearing realization.

As already implied, agriculture will grow only to supplement other interior industries which must provide a means of livelihood for the great mass of consumers. The current construction phases of the defence program may provide sufficient impetus to bring an additional 200 to 250 farms into full production, but it is unlikely to require more. Exploitation of Alaska's power resources including water, coal, and petroleum will create additional population pressures and support a larger number of producing farms.

\section{Agricultural research}

Following direct congressional action, agricultural research in Alaska was reorganized and intensified in 1947. Since then Territorial and federal appropriations annually have made available some $\$ 400,000$ to $\$ 500,000$ for this purpose. Research is now conducted jointly by the U.S. Department of Agriculture and the University of Alaska. Major efforts have concentrated on strengthening the dairy industry by increasing local feed supplies through better management practices and better crop varieties, by promoting farm efficiency, and by improving dairy herds through crossbreeding and introducing superior germ plasm. This program has already stepped up dairy efficiency: in the Matanuska Valley average milk production per cow in 1951 was 8,900 pounds as compared with 7,200 pounds in 1947 .

Other major research investigations have been made on fertilizer and soil management practices, on bromegrass nutrition, on searching for adapted cereal and forage varieties, on breeding, cultivating, and storing of potatoes, and on analysing markets and agricultural potentials. Supplementary projects have explored the use of native lumber resources for farm structures, have improved insect and weed control measures, and have shown the necessity for plant disease control on farms. Plans for the next biennium are limited largely 
to basic problems already under consideration. As additional funds become available, they will be used to enlarge the attack on the most basic and neglected field-that of animal nutrition in subarctic regions. Primary objectives are to determine the nutritional value of Alaska-grown foodstuffs, and to assess modern diets in Alaska.

To strengthen the current agricultural research program, which is chiefly concerned with production research, the following subjects require further study:

1. Winter survival mechanisms of plants: Extension of commercial agriculture into the Subarctic has given several clues concerning winter survival mechanisms of plants. Because most commercial crop plants were evolved in more southerly latitudes their conditioning mechanisms apparently fail to respond to controlling factors in a subarctic environment. This response failure is now being associated with photoperiodism. Changes in light quality and intensity may play a larger role in physiological preparation for winter than has generally been thought. If winter-hardiness factors can be isolated and studied in detail, this knowledge will benefit all production areas.

2. The importance of moisture deficiency as a limiting factor in arctic and subarctic food production: As production management practices intensify, efforts must be made to minimize the limiting features of seasonal moisture distribution and of absolute moisture deficits. The following questions should be studied: Can present irrigation systems and techniques be used in Alaska? What are the power requirements? How much water is needed? Will soil moisture retaining capacities limit the use of water? Will water temperatures limit plant response? What are the cost factors? What are the magnitude of crop responses and where is the point of limiting returns?

3. Reindeer: Large areas of arctic and subarctic land masses are adapted to extensive grazing. Reindeer can reproduce and grow in this environment. But what is the carrying capacity of the range? Is the range susceptible to improved management practices? How intensively can the range be used? Will reindeer respond to improved feeding and breeding practices? What is the nature and size of the reindeer market? What economic factors are limiting? What social factors? Is this a possible food crop that merits development?

In addition to these major production problems there are problems of living conditions, of marketing, and of utilization both of land and of food crops. Some of these are very closely related to production, because the answers will determine to a large extent whether or not additional farm development takes place. Unless farming in the Subarctic offers suitable incentives in terms of good family living, it will not be able to compete for labour and capital. The solutions of the following problems are needed:

1. To reduce high labour costs, specialized equipment must be designed and tested in spite of the present small market volume. 
2. Adequate and inexpensive housing for man and animals must be designed, and storage facilities must be adapted to the subarctic and arctic environments.

3. Cheaper methods of clearing and preparing land must be found. Some method must also be devised of financing developing farms. As long as the original entryman must carry the entire burden, farm expansion will be slow.

4. Finally, new markets, new products, and new processing methods must be developed if Alaska's agriculture is to become financially and numerically significant.

\section{Short bibliography}

Andrews, R., H. A. Johnson, and P. F. Martin. 1953. 'Dairy and potato farms in the Matanuska and Tanana valleys, 1951'. Alaska Agri. Expt. Sta. Mimeograpb Circular 3, $21 \mathrm{pp}$.

Day, T. H. 1950. "Physical land conditions in the Kenai-Kasilof Withdrawal Area". (Unpubl.) Soil Conservation Ser. U.S. Dept. Agri.

Davis, R. O. E. 1945. 'Explosibility and fire hazard of ammonium nitrate fertilizer'. U.S. Dept. Agri. Circular 719, 22 pp.

[F.A.O. Committee]. 1952. 'Agricultural programs of the United States: current and prospective'. Special Rept. to the Food and Agri. Organization of the United Nations: U.S. Dept. Agri. viii + 64 pp.

Hodgson, H. J. and A. H. Mick. 1952. "Alaska's soils and crops". What's New in Crops and Soils, Vol. 4, No. 7, pp. 9-11.

Irwin, D. L. and H. A. Johnson. 1952. 'Research activities of the Alaska Agricultural Experiment Station'. Alaska Agri. Expt. Sta. Proc. Rept. 7 pp.

Johnson, H. A. 1952. 'Alaska production statistics'. Alaska Agri. Expt. Sta. Proc. Rept.

Johnson, H. A. and D. L. Irwin. 1953. 'The position of agriculture in Alaska's current economy'. Alaska Agri. Expt. Sta. Sp. Rept. No. 1, 15 pp.

Johnson, H. A. and W. Calhoun. 1950. 'Markets for the products of cropland in Alaska', Alaska Agri. Expt. Sta. Prog. Rept. 50 pp.

Kellogg, C. E. 1941. 'The soils that support us'. New York: Macmillan Company, 370 pp.

Kellogg, C. E. and I. J. Nygard. 1951. 'Exploratory study of the principal soil groups of Alaska'. U.S. Dept. of Agri. Agri. Monograph No. 7, 138 pp.

Moore, C. A. 1952. 'Farming in the Matanuska and Tanana valleys of Alaska'. Alaska Agri. Expt. Sta. Bull. 14, 32 pp.

Rockie, W. A. 1946. 'Physical land conditions in the Matanuska Valley, Alaska'. U.S. Dept. Agri. Pbysics and Land Surv. No. 41, 32 pp.

Sherman, C. 1952. 'Alaska production statistics for 1952'. Alaska Dept. Agri. 6 pp.

Stone, K. H. 1952a. "Populating Alaska: the United States phase". Geogr. Rev. Vol. 42, pp. 384-404.

1952b. "Some geographic bases for planning new Alaskan settlement" in 'Science in Alaska'. Arctic Inst. Nortb Amer. Sp. Publ. No. 1, pp. 136-50. 